\title{
Crop productivity constraint in the Upper Ganga Canal Command
}

\author{
S. K. Tripathi \\ Department of Water Resources Development and Management, \\ Indian Institute of Technology, Roorkee, India
}

\begin{abstract}
The Upper Ganga Canal System is now about 167 years old. It was conceived, planned and executed by Sir Cautley as famine relief work in North India. The command area spreads into the Districts of Haridwar, Saharanpur, Muzaffarnagar, Meerut, Bulandshahar, Ghaziabad, Gautam Budh Nagar, Aligarh, Mathura, Agra, Etah, Mainpuri and Kanpur. The system was modernized in 1995. About 323 persons $/ \mathrm{km}^{2}$ area is the population pressure. Farmers follow intensive cultivation practice. Important canal water management constraints that affected the yield of sugarcane (Y1), rice (Y2) and wheat (Y3) were analyzed as Distance from Hardwar (km) as X1, CCA (ha)/cumec as X2, Field Size $\left(\mathrm{m}^{2}\right)$ as X3, Water Table (m) as X4, Size of Holding (ha) as X5, Occupancy (days/year) as X6, Clay content (\%) as X7 and Annual Rain (mm) X8. Regression analysis indicated that the size of holding of farmers affected the yield of these crops remarkably. Correlation study revealed the yields of sugarcane was affected by CCA (ha)/cumec negatively insignificantly whereas, rice and wheat yield was affected by land occupancy (days/year) and rainfall ( $\mathrm{mm})$ significantly and negatively. The rest of the variables affected positively and significantly. These findings revealed that planners and administrators may take initiative to encourage farmers to increase the size of their holdings by discouraging further fragmentation, making equitable water supply and improving soil fertility throughout the command. Keywords: distributaries, minor, command, crop, soil type, cultivable.
\end{abstract}

\section{Introduction}

India has a gross irrigated command of 90 mha spreading in different states and regions [1-3] of the country. Punjab, Haryana and Western Uttar Pradesh have 
$>80 \%$ area under irrigation by surface and ground water $[2,3]$. But in rest of the states, area under irrigation is $<40 \%[2,3]$. Productivity of crops in different parts of the country is highly variable and fluctuating. There are different reasons viz. excessive or short supply of water, soil fertility and soil health problem, weather variability, poor agronomic practices etc. assigned to it [3]. In view of the ever increasing population growth in the country a sustainable and ever increasing agricultural productivity is needed. In this task, the canal irrigated command areas have got a greater role to play.

The Upper Ganga Canal System constructed in 1854 is about 167 years old. It was conceived, planned and executed by Sir Cautley as a famine relief work in North India. The system got modernized in 1995 with the productivity proposed as $9.0 \mathrm{t} / \mathrm{ha} /$ year. The average productivity in the command during $2000-01$ is reported to be $4.7 \mathrm{t} / \mathrm{ha} /$ year only [1]. This shows a huge gap in the productivity level proposed and actually recorded which needs to be systematically identified to find ways and means to fill the gap.

Keeping the above points in view the study entitled "Crop Productivity Constraints in the Upper Ganga Canal Command" was undertaken.

\section{Description of project}

The Upper Ganga Canal (UGC) system commissioned in 1854 takes off from the river Ganga at Bheemgoda in Haridwar. This canal system was designed for protective irrigation during Rabi with the head discharge of 240 cumec. Therefore, a temporary diversion bund was only constructed every year immediately after the monsoons to feed the system. As the system of irrigated agriculture developed in the command, the demand of water for Kharif crops also increased. Therefore Bheemgoda weir across the river Ganga was constructed in 1920 to divert the river flows into canal round the year (Fig. 1).

The system was modernized with the construction of Bheemgoda Barrage for the increased head discharge to 350 cumec and culturable command extending to 1.2 mha. The Upper Ganga Canal system spreads between $27^{\circ} \mathrm{N}$ to $30^{\circ} \mathrm{N}$ latitude and $77^{\circ} 15^{\prime} \mathrm{E}$ to $78^{\circ} 40^{\prime} \mathrm{E}$ longitude. The districts of Haridwar, Saharanpur, Muzaffarnagar, Meerut, Bulandshahar, Ghaziabad, Gautam Budh Nagar, Aligarh, Mathura, Agra, Etah, Mainpuri and Kanpur are in the service command. In the head reach, farmers by and large do adopt agro forestry on the boundaries of their farm for obtaining additional income whereas in the tail reach farmers adopt only rice-wheat cropping system along with the cultivation of low water requiring crops viz. pearl millet, maize, gram, mustard etc.

The UGC system has a length of about $6750 \mathrm{~km}$ of irrigation channels and $4400 \mathrm{~km}$ of drains and escapes. The network of water distribution system consists of 5 branches (Main, Deoband, Anupsahar, Math and Hathras), 119 distributaries and about 250 minors. Each channel runs in a roster of one week on two weeks off during Winter (November-March) and two weeks on and two weeks off during Rainy season (June-September). Farmers receive water through "warabandi" system of water distribution. The Command area is also well drained and facilitated by 763 drains of different size and capacity. 


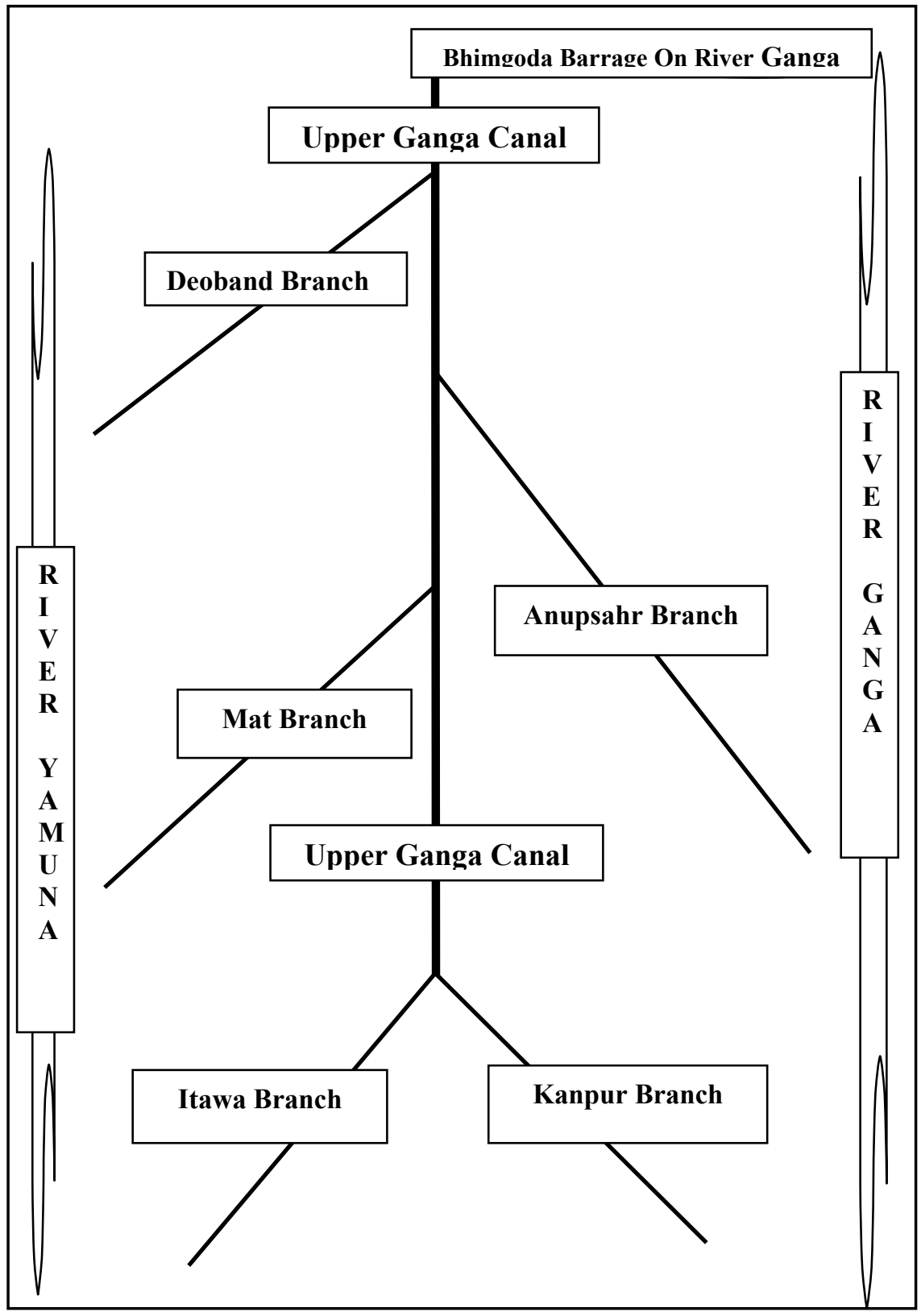

Figure 1: Line diagram of the Upper Ganga Canal System.

Agro-climatically, the command area varies from moist sub-humid sub tropic with $1050 \mathrm{~mm}$ rainfall (Haridwar at the Head reach in sugarcane zone) to dry sub humid sub tropic with $650 \mathrm{~mm}$ rainfall (Kanpur at the Tail reach in non 
sugarcane zone). Around $90 \%$ of annual rainfall is received during monsoon season (June to October). The Annual pan evaporation of the area is around $1500 \mathrm{~mm}$ in Head Reach $-1800 \mathrm{~mm}$ in the Tail Reach. The temperature varies from $-1^{\circ} \mathrm{C}$ to $4^{\circ} \mathrm{C}$ in December-January and $40^{\circ} \mathrm{C}$ to $45^{\circ} \mathrm{C}$ in May-June [4].

Soil type in the Upper Ganga Canal command is also highly variable. The head reach soils are predominantly the sandy loam whereas the tail reach soils are predominantly the clay loam. There are three distinct cropping zones viz. sugarcane (head reach), mixed sugarcane (middle reach) and non sugarcane (tail reach). Various crops that are grown in the command are: sugarcane, rice, wheat, black gram, green gram, maize, potato, red gram, sesame, sorghum, pearl millet, mustard, groundnut, linseed etc.

The main crops contributing to $>75 \%$ of the irrigation revenue in the command are sugarcane, paddy and wheat. Other crops such as maize, pearl millet, barley, mustard, pulses, groundnut, potato, vegetables, fodder crops etc. are also grown in the command but on a limited area through lift irrigation. This area use to be highly productive in the past but it is gradually decreasing due to intensive agricultural practice followed since the dawn of Green Revolution in India in 1971. The command area falling between Ganga and Yamuna rivers is very fertile but the Rice-Wheat cropping system with high yielding dwarf varieties adopted by the farmers has resulted into the nutrient mining of top $20 \mathrm{~cm}$ root zone layer. Although the farmers are very progressive and adopt a good intensive cultivation practice but they are losing its productivity at $20 \mathrm{Kgs} / \mathrm{ha} /$ year [5-7].

The command is also rich in groundwater therefore a large number of private owned shallow tube wells are constructed. In the upper reaches of the command deep tube wells are also installed by the Governments $[2,3]$. The command area is thickly populated (323 persons $\left./ \mathrm{km}^{2}\right)$ and is rising at about $2.8 \%$ [4].

\section{Methodology}

The command area was divided, for the sake of the convenience of study, into three crop zones viz. Sugarcane Zone (Haridwar and Muzaffarnagar) where sugarcane crop occupies $>50 \%$ cultivated area, partial Sugarcane (SM) Zone (Meerut and Ghaziabad) where sugarcane crop occupies about $25 \%$ of the cultivated area and non Sugarcane (NS) Zone (G. Budh Nagar, Aligarh and Mathura) where sugarcane is rarely seen. Deoband Branch in Sugarcane Zone, Anupshahar Branch for mixed Sugarcane Zone and Math Branch for non Sugarcane Zone was selected for further studies. Each Branch canal was divided into Head (1), Middle (2) and Tail (3) reaches. One Minor Canal from the each reaches of the branch canal was selected for detailed study. Thus a total of 9 Minor Canal were selected for the study. Each Minor Canal was further divided into Head (1), Middle (2) and Tail (3) reaches. Crops selected for the analysis were only sugarcane, rice and wheat. The description of channel selected for the study is given in Table 1. The average CCA and PPA was 1858 ha/ cumec and 755 ha/cumec respectively. A total of 135 farmers were selected 


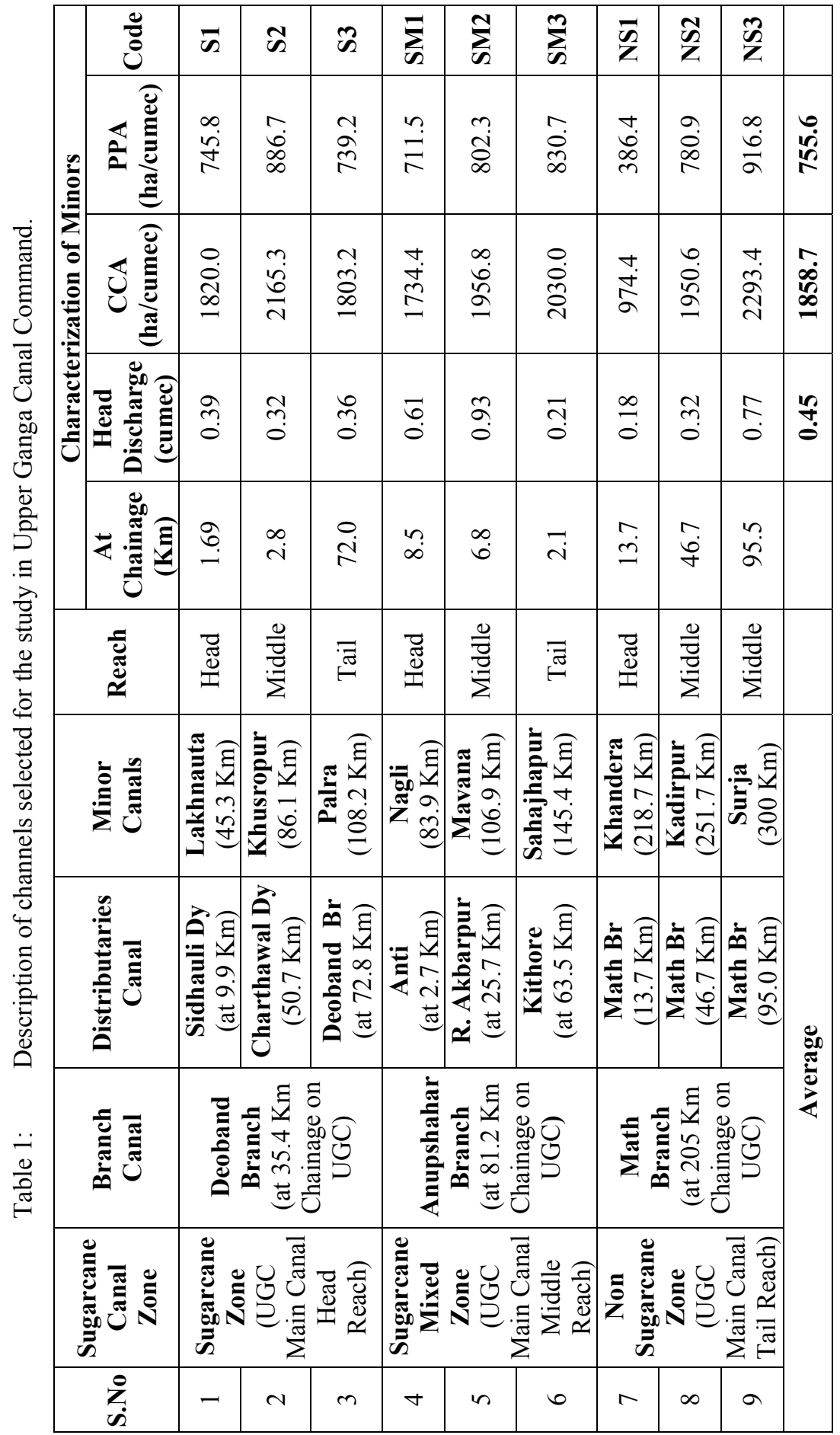


for interview. They were 45 from each branch canal and 15 from each minor canal and 5 from each reaches of the minor. A questionnaire was prepared. Farmers were interviewed to record the observations on different aspects of water management as well as the crop production. Inconsistency of information given by the farmers was corrected through cross examination. Recommended elements of observation were taken [6]. Data recorded was statistically analyzed.

Soil samples from different field sites of the command from the top $20 \mathrm{~cm}$ layer were collected and analyzed in the laboratory for their clay content $(<70 \mu)$ by sieve method. Weather data from Roorkee (for sugarcane zone/upper reach), Meerut (for mixed sugarcane zone/middle reach) and Kanpur (for non sugarcane zone/tail reach) was collected [4].

\section{Results and discussion}

The observations recorded and data analyzed are presented and discussed in the forthcoming paragraphs:

Data presented in Table 2 indicated the increase in the yield of all the three crops viz. sugarcane, rice and wheat from head to tail reach of the UGC system. There could be several reasons attributed to this but the fact is that the head reach farmers entered in the race of intensive agriculture practice and green revolution much ahead of middle and tail reach farmers. This might have caused nutrient mining therefore showing micronutrient deficiency in the crops in different in different parts of the command $[5,7]$. The clay content increased from sugarcane to non sugarcane zone (head to tail reach). This might also be contributing in recording such a strange yield loss pattern in the command.

The command of Upper Ganga Canal also spreads to different Agroclimatic conditions starting from sub humid sub tropic in the head reach to semi arid sub tropic in the tail reach. Agro climatically the tail reach of the command is more suited to the cultivation of sugarcane [8] but due to the lack of the infrastructural facilities in the area this crop is not popular. Agricultural planners may look into this issue and explore the feasibility of sugarcane popularization to increase the economic strength of the farmers in the tail reaches of the UGC command.

The predominant sowing time of various crops is early in the tail reach and little late in the head reaches of the command. This also might be affecting the yield pattern of these crops. The sugarcane crop in general is sown during April in the head reach but is sown during November in the tail reach. Due to this shift in the schedule of sugarcane sowing the head reach farmers are able to take a mixed crop as bonus during summer. The sowing of wheat is over by December $4^{\text {th }}$ week in the head reach whereas it is over by December $1^{\text {st }}$ week in the tail reach. It is a common observation recorded that the agricultural land use is very intensive marked by the increased land occupancy days in the head reach of the UGC command. This could be due to the increased availability of water to farmers in the head reach [7]. 


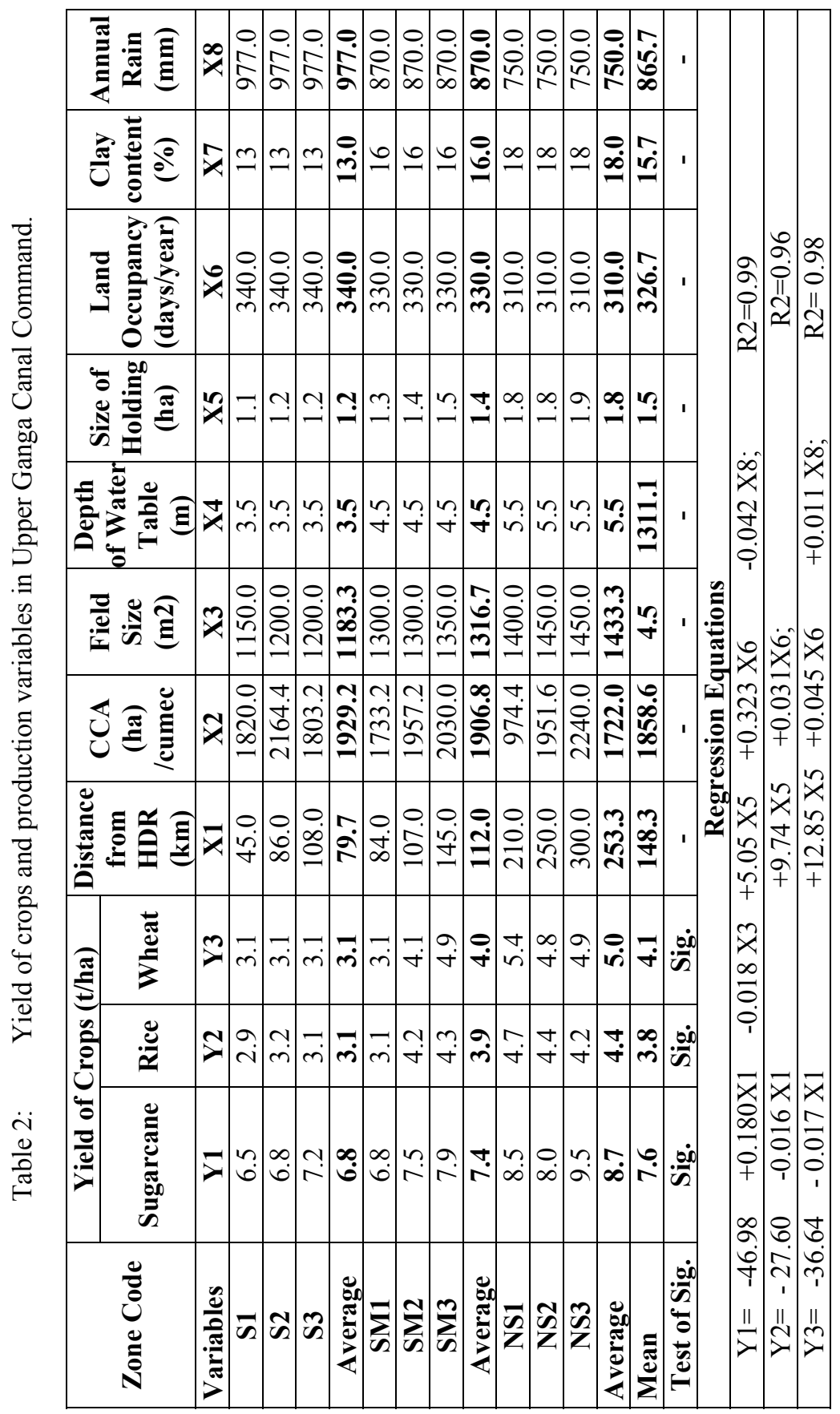


Regression analysis of data collected on yield (sugarcane as Y1, Rice as Y2 and Wheat as Y3) and production variables affecting the yield (distance from Haridwar (km) as X1, CCA (ha)/cumec as X2, field size $\left(\mathrm{m}^{2}\right)$ as $\mathrm{X} 3$, water table (m) as X4, size of holding (ha) as X5, land occupancy (days/year) as X6, clay content $(\%)$ as X7 and annual rainfall $(\mathrm{mm})$ as $\mathrm{X} 8)$ was done and presented in Table 2. Observation revealed that out of all the variables tested the size of holding of the farmer was found to affect most significantly and positively. Other variables also affected the yield but not so significantly. In order to increase the size of holding for improving water productivity and water use efficiency the national agricultural and water policy $[8,9]$ has recommended "collective" farming. Some corrective measures are required to be implemented at the state government level to remove social stigma coming in the implementation process. Since the holding size observed between $1.2-1.8$ ha per family which is already not very big but it relatively big in comparison to those holding $<0.5$ ha constituting the majority of the farmers in the society. Farmers with bigger size holding are maintaining farm equipment needed for various field operations. Another astonishing observation was that even the bigger size holding recorded actually did not belong to one person but to their whole family and cultivation was done in a unified (collective) manner. In other places it was found that farmers even went beyond the limits of their family and have got together pooling their land for agricultural management. Upper Ganga Canal system is a very important command as it is the grain and sugar basket of not only the Uttar Pradesh and Uttarakhand but also the entire country.

The correlation analysis made between crop yield (sugarcane, rice and wheat) and production variables (distance from Haridwar, CCA (ha0/cumec, field size $9 \mathrm{~m}^{2}$ ), depth of water table (m), size of holdings (ha), land occupancy (days/year), clay content (\%) and annual rainfall $(\mathrm{mm})$ are presented in Table 3. The analysis revealed that increasing the CCA (ha)/ cumec supply of water will adversely affect the yield of rice and wheat but not very significantly. The sugarcane crop although responded positive but not significantly. The increase in the CCA per unit water delivery may reduce the availability of irrigation water to crops that may cause water stress situation [6].

Table 3: $\quad$ Correlation between crop yield and production variables.

\begin{tabular}{|c|c|c|c|c|}
\hline \multicolumn{2}{|c|}{ Variables } & \multicolumn{3}{c|}{ Correlation Coefficient of Crops } \\
\cline { 3 - 5 } \multicolumn{2}{|c|}{} & Sugarcane & Rice & Wheat \\
\hline Distance from HDR (km) & X1 & 0.939 & 0.755 & 0.814 \\
\hline CCA (ha)/cumec & X2 & 0.009 & -0.221 & -0.237 \\
\hline Field Size (m2) & X3 & 0.859 & 0.856 & 0.873 \\
\hline Depth of Water Table (m) & X4 & 0.829 & 0.848 & 0.867 \\
\hline Size of Holdings (ha) & X5 & 0.927 & 0.870 & 0.910 \\
\hline Land Occupancy (days/year) & X6 & -0.849 & -0.817 & -0.855 \\
\hline Clay content (\%) & X7 & 0.803 & 0.852 & 0.860 \\
\hline Annual Rain (mm) & X8 & -0.835 & -0.845 & -0.868 \\
\hline
\end{tabular}


The land occupancy of crops (days/year) adversely and significantly affected the yield of all the three crops viz. sugarcane, rice and wheat. The increased occupancy might be instrumental in exhausting the mineral reserve (nutrients and micro nutrients) and their deficiency might be affecting the yield adversely. Deficiency of $\mathrm{Zn}$ and $\mathrm{S}$ in the soils of Indo Gangatic plain of which UGC command is a part has already been reported [5].

The annual rainfall situation also significantly and adversely affected the yield of all the three crops i.e. sugarcane, rice and wheat. In the UGC command, the rainfall during September is accompanied with very high wind velocities $(>10 \mathrm{~m} / \mathrm{sec})$ and sometimes even accompanied with hailstorm proves to be very much damaging to the crops of sugarcane and rice therefore its yield. During March and April the occurrence of rainfall coincides with the maturity stage of wheat crop but when it is accompanied with the hail storm it proves to be very damaging to yield. Sometimes the yield loss is as high as $90 \%$. Therefore the occurrence of rainfall during odd periods instead of improving the yield will reduce the yield. The command of UGC system normally faces the situation of western disturbances that results into devastating rainfall.

The rest of the variables (distance from Haridwar, size of fields $\left(\mathrm{m}^{2}\right)$, depth of water table, size of holdings and clay content of soil) responded positive and significantly. This indicates that their increase may help increasing the yield further.

\section{Summary and conclusion}

The Upper Ganga Canal system with a command of about $1.2 \mathrm{~m}$ ha is one of the biggest irrigation systems operating successfully in Uttarakhand and Uttar Pradesh (India) states of India over the past 167 years. Some of the observation recorded and analyzed on productivity constraints is summarized as follows:

1. Average yield of sugarcane, rice and wheat increased from sugarcane zone (head reach) to non sugarcane zone (tail reach) of the command. Appropriate soil nutrient management in the head reach is suggested to reverse the trend.

2. Agro climatic condition in head reach is sub humid subtropics whereas in the tail reach it is semi arid subtropics. In order to encourage the cultivation of sugarcane in the tail reach of the UGC command proper irrigation water management in the head reach is needed.

3. Regression analysis showed that the size of holding remarkably affected the average yield of sugarcane, rice and wheat crops in the command. Land laws preventing fragmentation of holing needs to be implemented.

4. Correlation study revealed that water supply CCA (ha)/cumec, size of land holding and rainfall condition affected the yield of sugarcane, rice and wheat negatively. Rest of the variables showed a positive and significant correlation. 
Based on the above findings it can be concluded that the main constraint for improving the productivity of crops in the Upper Ganga canal command is the reducing size of holding of the farmers. Government may design constitutional clause to arrest the further subdivision of holdings so that every farm family maintains an economic size of holding to adopt intensive cultivation practice.

\section{Acknowledgements}

The author is grateful to Ministry of Water Resources Govt. of India for making the funds available for undertaking this study. The author is also thankful to the research fellows' field staff that helped in the collection and analysis of data and giving useful observation clues.

\section{References}

[1] Agnihotri S.K., Statistical data of Uttarakhand and Uttar Pradesh. Jagran Prakashan Kanpur pp. 258, 2003.

[2] Anonymous, Agricultural Statistics at a Glance 2009. Published by Directorate of Statistics and Economics, Ministry of Agriculture, Government of India. pp 284, 2009.

[3] Anonymous, XIth Five year Plan Document. Published by Government of India Planning Commission. 2007.

[4] Tripathi S.K., Thirty Years of Rainfall Records of Roorkee. IIT Roorkee publication pp. 38, 2009.

[5] Dwivedi B.S., A.K. Shukla, V.K. Singh and R.L. Yadav, Sulphur fertilization for sustain productivity of Rice-Wheat system in western Uttar Pradesh. Published by PDCSR, Modipuram (ICAR) pp 35, 2001.

[6] Molden D.J, R. Sakhtivadivel, C.J. Perry and C.de Fraiture Indicators for comparing performance of irrigated agriculture. Published by International Water Management Institute Sri Lanka. Research report 20, pp. 26, 1998.

[7] Pandey R.K., B.S. Dwivedi and A.K. Sharma, Rice-wheat cropping system. Published by PDCSR, Modipuram (ICAR) pp 277, 1992.

[8] Anonymous, National Agricultural Policy 2000. Published by Ministry of Agriculture, Government of India. pp. 10, 2000.

[9] Anonymous, National Water Policy 2002. Published by Ministry of Water Resources, Government of India. pp. 16, 2002. 